\title{
Changing roles and new perspectives: towards market orientation in public transport
}

\author{
Sofia Molander ${ }^{1}$
}

Published online: 23 May 2017

(c) The Author(s) 2017. This article is an open access publication

\begin{abstract}
The general international trend of increasingly subjecting the public transport industry to market principles has been concretized via various developments in many countries. In line with this trend, there is an increased interest in public procurement processes as a model for public service delivery. Sweden is one of the leading countries where public procurement is the prevailing model for delivering public services. In accordance with the general trend, efforts have been made to make Sweden's public transport more sensitive to passenger needs, and to stimulate a competitive public transport system. For instance, a new Act, which came into effect on 1 January 2012, is aimed at fostering a customer-centric public transport system, with increased role clarity for the public transport actors. Since market-oriented strategies and public procurement processes are both receiving increased interest from the public transport industry, the market orientation of both public authorities and service providers in Sweden's public transport has been studied. Since market orientation is a process of change, a longitudinal approach was whereby the first study was conducted in the spring of 2011 and the second in the spring of 2014. All of Sweden's public transport authorities and the service providers that they stated as their major contract holders were asked to participate. In total, 184 respondents participated in the studies. The findings show that the industry as a whole has increased its organizational and inter-organizational efforts to both acquire knowledge of and respond to passenger needs. In particular, the public service providers have increased their involvement in market-oriented activities.
\end{abstract}

Keywords Public transport - Market orientation - Public procurement

Sofia Molander

sofia.molander@kau.se

1 Service Research Center/SAMOT, Karlstad University, 65188 Karlstad, Sweden 


\section{Introduction}

Over the last decades, substantial institutional changes have taken place in the European public transport scene (van de Velde 2014). Public procurement practices and the privatization of municipal operators are general characteristics of these institutional changes. These developments in public transport are aligned with the general movement in the public service sectors. Subjecting public services to market principles is one major strand of opinion being advocated in the stream of research labeled 'New Public Management' (NPM), where the basic assumptions are that market orientation improves public service performance (Walker et al. 2011) and that citizens' preferences should be used as the basis for formulating objectives (Vigoda 2002; Rourke 1992). In public transport research, market orientation has only recently been introduced and applied to a public transport context (Molander et al. 2012). The concept of market orientation operationalizes the notion that a market focus is essential, which is an underlying assumption in the development of NPM and the changes taking place in the public transport industry. The tangible and concrete conceptualization made by Kohli and Jaworski (1990) focuses on organizational activities and actions (Kohli and Jaworski 1990; Jaworski and Kohli 1993), defining market orientation as "the organizationwide generation of market intelligence pertaining to current and future customer needs, dissemination of the intelligence across departments and organizationwide responsiveness to it" (Kohli and Jaworski1990, 6).

The general trend of increasingly subjecting public transport industry to market principles has been concretized via various regulations and policies. In a public enquiry preceding Sweden's new public transport Act, which came into effect on 1 January 2012 (SFS 2010), it was concluded that a clear passenger perspective is needed, and that the new Act should foster a customer-centric public transport system in line with passenger needs (SOU 2009). Since customer orientation serves as a foundation for market-oriented activities, market orientation is a seemingly suitable theoretical foundation for examining how the customer-oriented approach being sought is manifested in the organizations responsible for delivering public transport. The new Act (SFS 2010) was also aimed at increasing role clarity for public transport actors. In this study, the market orientation of both public authorities and service providers is examined. In determining the organizational roles that exist in the market orientation of public transport, we also examine public authorities' and service providers' perceptions of the other actors' involvement in market-oriented activities. Market orientation is a process of change and is thus likely to increase over time if the involved actors are committed to a pursuit like this. Other processes, e.g. new regulations and policies, also imply change, indicating that the desired effects might not be visible immediately after coming into effect. Therefore, in order to examine whether and how approaches to market-oriented activities have evolved in public transport, we have adopted a longitudinal approach. As Sweden's new public transport Act came into effect on 1 January 2012, the first study was conducted in the spring of 2011 and the second in the spring of 2014. The new Act accentuates the prevailing trends in public transport, providing a research opportunity to examine the approach to market-oriented activities that has been taken by public authorities and service providers during this transformative phase of public transport. Examining the market orientation before and after this Act came into effect was a unique opportunity. However, the two market orientation studies should be seen in terms of being conducted on two occasions during a longer and ongoing process to achieve a market-oriented public transport system. 


\section{The case of Sweden's public transport}

In 1978, the Swedish Government ratified a legislative proposal stipulating that the municipalities and counties were to be responsible for local and regional public road transportation. In 1989, authorities were allowed to purchase transport services subject to competition using a public procurement procedure. Separating the responsibility to attend to citizens' needs (authorities) from the management of vehicle operation (operators) was consistent with the broad trend in European public transport (Pina and Torres 2001). However, direct awards and historical rights for municipal operators (or other operators owned by authorities) are far more dominant in countries like Germany, Austria, Switzerland, Spain, Italy, Belgium, Ireland, Poland, etc. (van de Velde 2008). Public procurement, on the contrary, is dominant in Sweden, Denmark, the Netherlands, France, and London; albeit with considerably divergent implementation. In Sweden, the vast majority of regional public transport is provided through procurements. Contracts regulate the agreements between the local public transport authorities in the regions and commercial operators (Trafa 2013). Implementing a public procurement system was initially very successful in lowering the cost of public transport, but the costs have increased over time and criticism has been aimed at cost being focused at the expense of quality and development. These are two of the driving forces in the great reform pressure that Sweden's public transport has experienced over the last two decades, leading to stepwise deand reregulation. Another important force is considered to be the more active positions, in issues relating to public transport, adopted by municipalities and counties due to public transport increasingly being seen as important to regional development and the environment. Another vital factor is believed to be customers' increasing demands for customer orientation and a more reliable public transport system (Enquist and Johnson 2013). The de- and reregulation have been concretized in various legislative actions. One reform is the market opening for long-distance personal transport by rail which came in to effect on October 1, 2010. Another major reform is the new Swedish Public Transport Act. A public inquiry (SOU 2009:39) together with an industry proposal for a new business model and role allocation, constituted the basis for the new public transport Act (Prop. 2009) which was adopted by Parliament in June 2010. These market openings aimed at improving market dynamics, diversifying the supply and lowering prices by allowing free entry on the market. The basic starting point for formulating the new Act was the need for a clear passenger perspective, and the fact that the new Act should foster a customer-centric public transport system in line with passenger needs (SOU 2009:39). Sweden's new public transport Act came into effect on 1 January 2012, bringing with it the new rules for market access, entailing that the commercial entities can operate in parallel with the contracted services. All types of transport operators, including the commercial players, will have to submit information on the range of services they offer, which will then be fed into a shared system for passenger information. The liberalized rules governing market access are aligned with one of five principles deriving from transport policy objectives (Prop. 2008), which Parliament has decided should guide the choice of control mechanism and the prioritization and allocation of funding:

- Customers should be allowed great freedom of choice in determining how they want to travel and how transfers are to be achieved.

- Decisions regarding transport services should be decentralized.

- Collaboration within and between different modes of transport should be advanced.

- Competition between transport operators and transport alternatives should be advanced. 
- The socioeconomic costs of transport should be a starting point when political transport policies are designed.

These principles have also been guiding the formation of new public transport authorities responsible for political decisions and strategic development plans as well as for the scope of the public transport on offer in each region. Each county had to have a regional public transport authority that decides on regional transport provision programs specifying the long-term goals of regional public transport. The public transport objectives and these guiding principles are expressions of an ambition to create distinct political governance, while giving the passenger a voice. The principles guiding the new public transport system support the fact that a market-oriented approach entails more than subjecting the industry to a market principle such as the competitive market. The transformation toward passenger-centric public transport entails public authorities and service providers having a shared understanding of the importance of focusing on their customers' needs.

A balance between political governance and market thinking is desirable in many public service contexts. The contracting of services via public procurement processes, as in Sweden's public transport system, can be seen as one strategy for achieving this balance. Studying market orientation in this empirical context is well-timed since other systems of public transport and public services are believed to be moving in this direction. The next section elaborates on the concept of market orientation vis-á-vis the empirical context.

\section{Public transport and market orientation}

As indicated in the previous section, the principles deriving from transport policy objectives are well aligned with a market-oriented approach to delivering services, something which will be exemplified further in this section. In this study, we adopt Kohli and Jaworski's (1990) and Jaworski and Kohli (1993) three-dimensional conceptualization of market orientation. The dimensions - i.e. intelligence generation, intelligence dissemination, and responsiveness - are thus discussed from a public transport perspective regarding contextual aspects and empirical research.

Intelligence generation refers to a broadened customer focus by means of which it is important to foresee the needs of both future and existing customers, and to include market factors that influence their needs and preferences. As for most theoretical concepts however, the practical implementation is often complicated by various factors. For instance, even when directly surveying users and non-users of public transport, there can be differences between revealed preferences and stated preferences (e.g. Eboli and Mazzulla 2008) that can have misguiding effects on decisions being based on generated intelligence. Revealed preference data and travel data is therefore intelligence which can reflects passenger preferences with less risk of response bias. Hence, direct passenger communication as well as the usage of good information technologies provides important information which can be used in responsive actions.

Two of the guiding principles for public transport concern freedom of choice and competition between operators. In such a context, intelligence generation becomes crucial to public transport operators. Operators need to be updated about what services are being offered by their competitors, and they depend on good knowledge of their customers' needs in order to offer a service that meets those needs. Another example of intelligence generation in public transport is when actors proactively analyze the possible effects of 
rules and regulations that can affect existing and future passengers, e.g. increased congestion charges. In public transport research, many scholars have adopted a passenger perspective when studying passenger preferences, satisfaction, and perceived quality (e.g. Redman et al. 2013; Fellesson and Friman 2008). However, little research has addressed public transport organizations' intelligence-generating activities. As there are several actors on the public transport scene, one important question concerns the different organizations' roles and responsibilities in generating intelligence. Since one stated goal of the new Act was to create more clearly-defined roles for the actors (SOU 2009:39), it is implied that the roles and responsibilities of the various public transport actors have been defined too vaguely, something which is likely to have an impact on organizational and inter-organizational activities concerning intelligence generation. For instance, it is known that both public transport operators are surveying passengers, but depending on the role of the actors, the content of these surveys and the actors' possibilities to act upon the generated intelligence might vary. Although roles can be defined more clearly on a local level, there is a risk of misallocations in the sense that it does not foster the development of clarity and transparency aimed for in the new Act.

Intelligence dissemination concerns the communication of market information by all the departments of an organization (Kohli and Jaworski 1990), having been described as the process of distributing the intelligence generated within the organization (Maltz and Kohli 1996). The intelligence dissemination is the bridge between intelligence generation and responsiveness, and in order for the responsiveness to be aligned with the generated intelligence, it must function properly. As previously mentioned, several actors are involved in the delivery of public transport services, making intelligence dissemination an interorganizational concern as well. Market orientation in a multi-actor context is suggested to induce relationship management tasks such as coordination, conflict resolution, and adaptation (Helfert et al. 2002) — aspects that are highly dependent on communication and dissemination activities. An effective dissemination process is also closely related to the guiding principles for achieving transportation goals (Prop. 2008). Collaboration within and between different modes of transport, as does a decentralized public transport system, requires dissemination by all public transport actors. What and how to disseminate requires that the roles of the actors are made clear, and that there is an understanding of what intelligence an actor is expected to generate and why. For instance, surveying passengers requires that the responsible actor has knowledge of what intelligence that is desired, how to best generate it and how to make it visible and comprehensible for those in the organization and other concerned organizations responsible for responsive actions. In public transport research, very few studies have addressed intelligence dissemination. The public transport studies that can be related to intelligence dissemination have focused on interorganizational aspects that can be argued to have a disseminating effect, e.g. benchmarking and collaboration (Molander et al. 2012).

Responsiveness refers to the actions taken by organizations in response to the intelligence being generated and disseminated (Kohli and Jaworski 1990). Responsiveness is manifested in actions such as selecting target markets, designing and offering products and services, and other activities that influence the offering being made to the customer. In public transport, actors have put much effort into actions aimed at improving the service, e.g. bus TV, free Wi-Fi, better travel information, nicer stations and increased marketing. In public transport research, most studies relating to responsiveness have primarily focused on physical improvements (e.g. speed, service frequency) without addressing the link between responsiveness and the generated intelligence (Molander et al. 2012). Therefore, knowledge is also lacking with regards to the role of generated intelligence in the public 
transport actors' decision processes for improvements. A market oriented approach might not entail that more improvements are being made, but rather that the improvements are better mirroring the needs of the passengers and that generated intelligence play a vital role in designing and improving services. However, even when generated intelligence constitutes the base for action and responses, there are aspects that complicate responsiveness in practice. For instance, customers are not a homogenous group which could mean that one group of customers can benefit from a change whereas another group experience increased negative perception of the service. To continuously make changes in the service, although they might be perceived as improvements by the majority of users, might also cause negative perceptions due to lesser stability and continuity of the service. As for intelligence generating activities, organizational roles and responsibilities are important aspects of responsiveness in the public transport context. Empirical research into public authorities' and services providers' roles during responsive actions is lacking; however, the new Act (Prop. 2009), for instance, implies that it is an issue being debated on the policy level. In other words, public transport research into aspects of market orientation lacks both a comprehensive approach to market-oriented activities and a multi-actor perspective. The present study addresses these research gaps by adopting a broad market orientation perspective and by surveying the two primary actors involved in the delivery of public transport services-public transport authorities and service providers.

\section{Method}

\section{Design}

Public authorities' and service providers' market orientation has been surveyed using an adapted version of the MARKOR scale (Kohli et al. 1993). The MARKOR scale is derived from the three dimensions of market orientation-i.e. intelligence generation, intelligence dissemination, and responsiveness. In addition, the scale has been shown to be a valid and reliable measure of market orientation in various settings, indicating its universal applicability (e.g., Kara et al. 2005; Varela and del Río 2003). Our adapted MARKOR scale consists of 3 items that measure activities regarding intelligence generation (e.g. customer surveys), 3 items that measure intelligence dissemination (e.g. meetings at which customers' needs are addressed), and 5 items that measure responsiveness (e.g. efforts to make changes that are aligned with customers' needs). In responding to the items which were formulated as statements, the respondents assessed the degree of market orientation within their own organizations. As in the original MARKOR scale, the items on the adapted scale were anchored using a five-point Likert scale where 1 corresponds to "strongly disagree" and 5 corresponds to "strongly agree". An overall measure of the level of market orientation was computed by averaging the scales for intelligence generation, dissemination, and responsiveness. In addition, 8 items were added in order to explicitly measure the respondents' perceptions of their partners' engagement in their dyad's market orientation. These items were formulated to capture the relational roles of aspects of intelligence generation (e.g. which dyad members take responsibility for customer surveys), intelligence dissemination (e.g. meetings at which dyad members address customers' needs), and responsiveness (e.g. joint efforts to make changes aligned with customers' needs). The questionnaire was translated into Swedish, with additional minor language changes being made in order to adapt the items to the specific public transport context. 
The questionnaire was used in two studies, conducted during the spring of 2011 and the spring of 2014. In the first study, the respondents were given the opportunity to make comments at the end of the questionnaire. As the second study was conducted after the new Act had passed into law, the questionnaire then concluded with an open-ended question where the respondents were asked to describe how they perceived the changes in regulations to have affected their collaborations with other public transport actors.

\section{Data collection}

\section{Spring of 2011: study 1}

As an initial step in the sampling procedure, the CEO and the Marketing Manager of every registered public transport authority (PTA) in Sweden were contacted and asked to participate. The manageable number of authorities (26) enabled a total population sampling approach to be used during this initial step of the procedure. The second step was to recruit public transport service providers to participate in the study. As public service dyads are in focus in this study, it was of importance to identify the PTAs' primary service providers, thus making a chain referral sampling method (Wejnert and Heckathorn 2011) suitable. The core of the technique lies in recruiting new respondents via the initial respondents. The referral chains were short but numerous; each of the initial 52 buyer respondents was asked to provide the contact information of the provider with whom they formed their primary partnerships. They were also asked to convey information about the other members of their own organization which they considered to have the knowledge needed to participate in the study. In total, 169 questionnaires were sent out over a period of 12 weeks. Two reminders were sent via e-mail to those who did not respond to the initial request. The final sample consisted of 47 buyer respondents and 40 provider respondents (56.6\% response rate).

\section{Spring of 2014: study 2}

Study 2 was conducted using the same procedure as Study 1; the CEO and the Marketing Manager of every registered public transport authority (PTA) in Sweden were contacted and asked to identify their primary dyad affiliations. This procedure ensured that the second sample included respondents with appropriate roles within the organization, something which was deemed to be of greater importance than including the same respondents as in the first sample. Also, repeating the procedure used in Study 2 ensured that the current major partnerships were assessed. In total, 162 questionnaires were sent out over a period of 15 weeks. Two reminders were sent via e-mail. The final sample consisted of 48 buyer respondents and 49 provider respondents (59.9\% response rate).

\section{Findings}

This section presents and discusses the results of the subscales measuring the public transport authorities' and service providers' intelligence generation, intelligence dissemination and responsiveness. 


\section{Intelligence generation}

In the second study, operators report a greater level of agreement with the statement that the organization frequently surveys its passengers, while the public transport authorities do not report an increase. This is indicative of a partial reallocation of responsibilities, and/or a change in the providers' approach to intelligence-generating activities. This is supported by one public authority respondent who, in open comments, reports that; "[the] responsibility has been reallocated to [the] service providers". In line with this, the providers also agree more strongly as regards quickly detecting changes in passenger attitudes during the second study. However, both studies show that the public authorities are the ones mainly responsible for passenger surveys, suggesting that they remain in control of the intelligence-generating activities. Moreover, Study 2 shows that both the public authorities and the service providers report having increased knowledge of their passengers' needs and preferences due to their membership of the dyad. This suggests that the relationship between the authorities and the providers has become more collaborative, and that their intelligence dissemination is more satisfactory (Table 1).

Table 1 Intelligence generation items

\begin{tabular}{|c|c|c|c|c|c|c|c|c|}
\hline \multirow[t]{2}{*}{ Item } & \multirow[t]{2}{*}{ Actor $^{\mathrm{a}}$} & \multicolumn{2}{|l|}{2011} & \multicolumn{2}{|l|}{2014} & \multirow[t]{2}{*}{$t^{1}$} & \multirow[t]{2}{*}{$t^{2}$} & \multirow[t]{2}{*}{$t^{3}$} \\
\hline & & M & SD & M & SD & & & \\
\hline \multirow{2}{*}{$\begin{array}{l}\text { 1. We often survey our passengers } \\
\text { to find out their needs and } \\
\text { preferences }\end{array}$} & Buyers & 3.96 & 1.16 & 3.92 & 1.17 & .17 & \multirow[t]{2}{*}{$1.85^{*}$} & \multirow[t]{2}{*}{.43} \\
\hline & Providers & 3.45 & 1.40 & 3.82 & 1.13 & -1.34 & & \\
\hline \multirow{2}{*}{$\begin{array}{l}\text { 2. We are quick to detect changes in } \\
\text { attitude in our passengers }\end{array}$} & Buyers & 3.13 & 0.74 & 3.08 & 1.15 & .21 & \multirow[t]{2}{*}{.97} & \multirow[t]{2}{*}{-.94} \\
\hline & Providers & 2.93 & 0.92 & 3.27 & 0.70 & $-1.79 *$ & & \\
\hline \multirow{2}{*}{$\begin{array}{l}\text { 3. We quickly detect fundamental } \\
\text { shifts in our industry (e.g. } \\
\text { competition, technology, rules and } \\
\text { regulations) }\end{array}$} & Buyers & 3.57 & 0.88 & 3.67 & 0.75 & -.55 & \multirow[t]{2}{*}{.38} & \multirow[t]{2}{*}{-.57} \\
\hline & Providers & 3.50 & 0.93 & 3.76 & 0.78 & -1.41 & & \\
\hline \multirow{2}{*}{$\begin{array}{l}\text { 4. Our dyad membership contributes } \\
\text { to our knowledge of passengers' } \\
\text { needs and preferences }{ }^{b}\end{array}$} & Buyers & 3.32 & 1.02 & 3.58 & 0.85 & .15 & \multirow[t]{2}{*}{-.64} & \multirow[t]{2}{*}{-.45} \\
\hline & Providers & 3.47 & 1.24 & 3.67 & 1.13 & -.79 & & \\
\hline \multirow{2}{*}{$\begin{array}{l}\text { 5. In the PTA/operator dyad, } \\
\text { passenger surveys are mainly our } \\
\text { responsibility }\end{array}$} & Buyers & 4.02 & 1.11 & 4.13 & 0.94 & -.49 & \multirow[t]{2}{*}{$6.55^{* *}$} & \multirow[t]{2}{*}{$6.81^{* *}$} \\
\hline & Providers & 2.40 & 1.20 & 2.63 & 1.20 & -.91 & & \\
\hline
\end{tabular}

\footnotetext{
a Study 1: Buyers $=47$ respondents; Providers $=40$ respondents; Study 2: Buyers $=48$ respondents; Providers $=49$ respondents

b Measures inter-organizational aspects of market orientation

$\mathrm{T}^{1} T$ test, study 1 vs. study 2

$\mathrm{T}^{2} T$ test, buyers versus providers, study 1

$\mathrm{T}^{3} T$ test, buyers versus providers, study 2

$* 0.1<p>0.05$

** $p \leq 0.05$
} 
Table 2 Intelligence dissemination items

\begin{tabular}{|c|c|c|c|c|c|c|c|c|}
\hline \multirow[t]{2}{*}{ Item } & \multirow[t]{2}{*}{ Actor $^{\mathrm{a}}$} & \multicolumn{2}{|c|}{ Study 1} & \multicolumn{2}{|c|}{ Study 2} & \multirow[t]{2}{*}{$t^{1}$} & \multirow[t]{2}{*}{$t^{2}$} & \multirow[t]{2}{*}{$t^{3}$} \\
\hline & & M & SD & M & SD & & & \\
\hline \multirow{2}{*}{$\begin{array}{l}\text { 1. We often have internal meetings } \\
\text { at which we discuss our } \\
\text { passengers' needs, requirements } \\
\text { and opinions }\end{array}$} & Buyers & 3.66 & 0.82 & 3.81 & 0.79 & -.93 & \multirow[t]{2}{*}{1.19} & \multirow[t]{2}{*}{-.50} \\
\hline & Providers & 3.43 & 1.01 & 3.90 & 0.90 & $-2.34 * *$ & & \\
\hline \multirow{2}{*}{$\begin{array}{l}\text { 2. When something important } \\
\text { happens in our industry, this } \\
\text { information is quickly } \\
\text { communicated within our } \\
\text { organization }\end{array}$} & Buyers & 3.74 & 0.99 & 3.65 & 0.74 & .53 & \multirow[t]{2}{*}{-.03} & \multirow[t]{2}{*}{$-1.93 *$} \\
\hline & Providers & 3.75 & 0.98 & 3.96 & 0.86 & -1.13 & & \\
\hline \multirow{2}{*}{$\begin{array}{l}\text { 3. Information about customer } \\
\text { needs is communicated to all } \\
\text { levels of our organization on a } \\
\text { regular basis }\end{array}$} & Buyers & 3.23 & 1.13 & 3.04 & 1.05 & .86 & \multirow[t]{2}{*}{-.26} & \multirow[t]{2}{*}{$-1.86^{*}$} \\
\hline & Providers & 3.30 & 1.22 & 3.43 & 1.00 & -.55 & & \\
\hline \multirow{2}{*}{$\begin{array}{l}\text { 4. The members of the dyad meet } \\
\text { frequently to discuss their } \\
\text { passengers' needs, requirements } \\
\text { and opinions }\end{array}$} & Buyers & 3.19 & 1.10 & 3.42 & 0.99 & -1.08 & \multirow[t]{2}{*}{-.24} & \multirow[t]{2}{*}{-1.18} \\
\hline & Providers & 3.25 & 1.24 & 3.65 & 0.99 & $-1.71 *$ & & \\
\hline \multirow{2}{*}{$\begin{array}{l}\text { 5. When something important } \\
\text { happens in our industry, this } \\
\text { information is quickly } \\
\text { communicated to dyad members }\end{array}$} & Buyers & 3.53 & 0.91 & 3.25 & 0.76 & $1.65 *$ & \multirow[t]{2}{*}{$1.95^{* *}$} & \multirow[t]{2}{*}{-.47} \\
\hline & Providers & 3.18 & 0.78 & 3.33 & 0.85 & -.87 & & \\
\hline
\end{tabular}

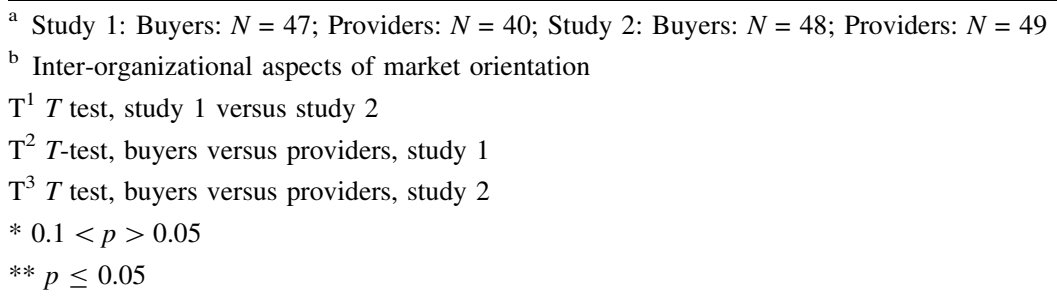

\section{Intelligence dissemination}

The second study indicates that meetings at which passengers' needs, requirements and opinions are discussed have become more frequent both within public authority organizations and provider organizations, and between the parties, within the dyads (see Table 2). The service providers report a markedly larger increase, which might be explained by reallocations of responsibility resulting in the provider respondents' perception of having a mandate to influence and engage in intelligence generating and disseminating activities. While the providers report an improvement in the flow of communication within the focal organization, and between the dyad members, the public authorities report a decrease. Several open comments suggest that the public authorities perceive the new regulations to have hampered the communication processes. For instance, one public transport authority respondent reports that changed regulations have resulted in; "increased bureaucracy and growing demands regarding collaboration due to the number of actors having increased". Similarly, others report that there are; "protracted decision-making processes" and that relationships have become "cumbersome". Concerns over the effects of new regulations can partly be considered as an attribute of a change process; however, the new Act does contain aspects of increased complexity regarding decision-making; it infers more 
governmental control over the local public transport authorities (SOU 2009:39). Also, several reports conclude that the national authorities that are important to the reforms have adopted a passive attitude (Trafa 2014), for instance neglecting to improve rail capacity allocation and to support Public Transport Act implementation by the regional public transport authorities.

\section{Responsiveness}

As displayed in Table 3, both public authorities and service providers report increased activity regarding responsive behavior. Both parties are more involved in aligning their service developments with their passengers' needs, and they are more reactive to changes

Table 3 Responsiveness items

\begin{tabular}{|c|c|c|c|c|c|c|c|c|}
\hline \multirow[t]{2}{*}{ Item } & \multirow[t]{2}{*}{ Actor $^{\mathrm{a}}$} & \multicolumn{2}{|c|}{ Study 1} & \multicolumn{2}{|c|}{ Study 2} & \multirow[t]{2}{*}{$t^{1}$} & \multirow[t]{2}{*}{$t^{2}$} & \multirow[t]{2}{*}{$t^{3}$} \\
\hline & & M & SD & M & SD & & & \\
\hline \multirow{2}{*}{$\begin{array}{l}\text { 1. We periodically review our } \\
\text { service development efforts to } \\
\text { ensure that they are in line with } \\
\text { what the passengers want }\end{array}$} & Buyers & 3.30 & 0.86 & 3.52 & 0.92 & -1.22 & -1.51 & -1.18 \\
\hline & Providers & 3.60 & 1.01 & 3.73 & 0.86 & -.68 & & \\
\hline \multirow{2}{*}{$\begin{array}{l}\text { 2. We take steps when something } \\
\text { changes in our industry }\end{array}$} & Buyers & 3.51 & 0.69 & 3.71 & 0.71 & -1.38 & $-1.84^{*}$ & $-2.36^{* *}$ \\
\hline & Providers & 3.83 & 0.90 & 4.04 & 0.68 & -1.29 & & \\
\hline \multirow{2}{*}{$\begin{array}{l}\text { 3. When we find that passenger } \\
\text { needs require us to change our } \\
\text { services, we make concerted } \\
\text { efforts to do so }\end{array}$} & Buyers & 3.98 & 0.74 & 4.13 & 0.61 & -1.06 & .02 & .32 \\
\hline & Providers & 3.97 & 0.83 & 4.08 & 0.73 & -.64 & & \\
\hline \multirow{2}{*}{$\begin{array}{l}\text { 4. The activities of our organization } \\
\text { are well coordinated }\end{array}$} & Buyers & 3.38 & 0.77 & 3.38 & 0.82 & .05 & -1.58 & $3.17 * *$ \\
\hline & Providers & 3.65 & 0.80 & 3.86 & 0.68 & -1.32 & & \\
\hline \multirow{2}{*}{$\begin{array}{l}\text { 5. At our organization, we prioritize } \\
\text { customer complaints }\end{array}$} & Buyers & 4.23 & 0.60 & 4.15 & 0.71 & .65 & -.27 & $-2.91 * *$ \\
\hline & Providers & 4.28 & 0.82 & 4.53 & 0.58 & $-1.72 *$ & & \\
\hline \multirow{2}{*}{$\begin{array}{l}\text { 6. In the PTA/operator dyad, } \\
\text { customer complaints are mainly } \\
\text { our responsibility }^{\mathrm{b}}\end{array}$} & Buyers & 3.96 & 1.10 & 4.17 & 0.88 & -1.02 & .84 & $1.66^{*}$ \\
\hline & Providers & 3.75 & 1.19 & 3.80 & 1.30 & -1.17 & & \\
\hline \multirow{2}{*}{$\begin{array}{l}\text { 7. Adapting to changes in the } \\
\text { industry is made easier by our } \\
\text { dyad membership }^{\text {b }}\end{array}$} & Buyers & 3.57 & 0.90 & 3.91 & 0.88 & $-1.85^{*}$ & .12 & .74 \\
\hline & Providers & 3.55 & 1.04 & 3.78 & 0.96 & -1.06 & & \\
\hline \multirow{2}{*}{$\begin{array}{l}\text { 8. Changes required in order to } \\
\text { meet passenger needs are made in } \\
\text { collaboration with dyad } \\
\text { members }\end{array}$} & Buyers & 3.72 & 0.85 & 3.73 & 0.82 & -.03 & .99 & -.96 \\
\hline & Providers & 3.53 & 1.01 & 3.90 & 0.92 & $-1.82^{*}$ & & \\
\hline \multirow{2}{*}{$\begin{array}{l}\text { 9. Collaboration between dyad } \\
\text { members is well coordinated }\end{array}$} & Buyers & 3.45 & 0.69 & 3.31 & 0.90 & .82 & .81 & -1.44 \\
\hline & Providers & 3.30 & 0.99 & 3.57 & 0.87 & -1.38 & & \\
\hline
\end{tabular}

\footnotetext{
${ }^{\text {a }}$ Study 1: Buyers: $N=47$; Providers: $N=40$; Study 2: Buyers: $N=48$; Providers: $N=49$

b Interorganizational aspects of market orientation

$\mathrm{T}^{1} T$ test, study 1 versus study 2

$\mathrm{T}^{2} T$ test, buyers versus providers, study 1

$\mathrm{T}^{3} T$ test, buyers versus providers, study 2

* $0.1<p>0.05$

** $p \leq 0.05$
} 
within the industry. In particular, Study 2 shows an increase in the perceived value of membership of the dyad when it comes to adapting to these changes. In line with this progress, the providers also report an increase in their collaboration with public authorities, as well as an increase in the coordination of that collaboration. Somewhat contradictorily, the public authorities do not report an increase in the coordination of the collaboration, or in the collaboration itself. Although the questionnaire addressed the dyadic relationship specifically, the more general development of the processes and relationships of the public transport actors might be one explanation for the asymmetric perception of this development. The increased bureaucracy perceived by public authorities can have an impact on communications with other actors, as well as the opportunity, or mandate, to be responsive. A Transport Analysis report conclude that regional public transport authorities do not appear to view commercial services as a potential resource and as a complement to public service obligations (Trafa 2014). Partly, this is believed to be explained by the lack of national efforts to aid transport authorities in implementing the Swedish Public Transport Act. At the same time, the providers report that the "opportunities to collaborate with other actors have increased", and that the service providers are "increasingly able to collaborate in relationships that were previously managed by public authorities". This is supportive of the previously-mentioned notion that the responsibilities have been reallocated. However, Study 2 indicates that the public authorities remain in control of responsive activities such as handling customer complaints, even though the providers report a higher degree of prioritization of customer complaints than do the public authorities. As with intelligencegenerating activities, this points to the fact that the public authorities remain largely in control of responsive activities, too. Of all the items in the questionnaire, the priority of customer complaints is the statement with which both the public authorities and the providers agree most strongly, indicating that this is an issue which is being focused on in the dyads.

\section{Overall market orientation and development of the industry}

The overall market orientation was measured by averaging the scales for intelligence generation, dissemination, and responsiveness. Hence, each dimension was given the same importance in the overall index regardless of the number of items relating to each dimension. The items measuring the inter-organizational aspects of market orientation were excluded from the overall market orientation index. The overall market orientation index shows that the service providers have increased their involvement in market-oriented activities significantly, while the public authorities' overall involvement in market-oriented activities remains relatively unchanged. Although the increase in market orientation is more evident in the service providers, the results also indicate an increase in inter-organizational efforts since the respondents agree more strongly with statements regarding inter-organizational activities and benefits (Table 4).

Based on these results, one might ask if there are any indications of increased customer satisfaction, or increased travel. Those variables where not captured in the present enquiry, but there are secondary data that might be used as complement. Kollektivtrafikbarometern [the public transport barometer] is an industry-wide quality and attitude survey that surveys both the passengers and the public throughout the country every year.

Kollektivtrafikbarometern (2015) indicates a significant increase in passenger satisfaction between 2010 and 2014. In 2014, 81 percent of passengers report being satisfied with their most recent journey, while only $62 \%$ are satisfied with their local public transport authority. One explanation for this lower level of satisfaction with the public authority 
Table 4 MARKOR Index Table

\begin{tabular}{|c|c|c|c|c|c|c|c|c|c|}
\hline \multirow[t]{2}{*}{ Index } & \multirow[t]{2}{*}{ Measurement } & \multirow[t]{2}{*}{ Actor $^{\mathrm{a}}$} & \multicolumn{2}{|c|}{ Study 1} & \multicolumn{2}{|c|}{ Study 2} & \multirow[t]{2}{*}{$t^{1}$} & \multirow[t]{2}{*}{$t^{2}$} & \multirow[t]{2}{*}{$t^{3}$} \\
\hline & & & M & SD & M & SD & & & \\
\hline \multirow{3}{*}{$\begin{array}{l}\text { Overall } \\
\text { market } \\
\text { orientation }\end{array}$} & \multirow{3}{*}{$\begin{array}{l}\text { An average of the items } \\
\text { measuring } \\
\text { intelligence } \\
\text { generation, } \\
\text { intelligence } \\
\text { dissemination, and } \\
\text { responsiveness }\end{array}$} & Buyers & 3.59 & 0.54 & 3.61 & 0.53 & -0.15 & 0.33 & $-1.86^{*}$ \\
\hline & & Providers & 3.55 & 0.69 & 3.81 & 0.51 & $-2.02 * *$ & & \\
\hline & & All & 3.57 & 0.61 & 3.71 & 0.53 & $-1.63^{*}$ & & \\
\hline
\end{tabular}

a Study 1: Buyers: $N=47$; Providers: $N=40$

Study 2: Buyers: $N=48$; Providers: $N=49$

$\mathrm{T}^{1} T$ test, study 1 versus study 2

$\mathrm{T}^{2} T$ test, buyers versus providers, study 1

$\mathrm{T}^{3} T$ test, buyers versus providers, study 2

$* 0.1<p>0.05$

** $p \leq 0.05$

Table 5 Passenger satisfaction and public transport's market share Source Kollektivtrafikbarometern (2015)

\begin{tabular}{llllll}
\hline & $\begin{array}{l}2010 \\
(\%)\end{array}$ & $\begin{array}{l}2011 \\
(\%)\end{array}$ & $\begin{array}{l}2012 \\
(\%)\end{array}$ & $\begin{array}{l}2013 \\
(\%)\end{array}$ & $\begin{array}{l}2014 \\
(\%)\end{array}$ \\
\hline $\begin{array}{l}\text { Passenger satisfaction with their most recent journey using } \\
\text { the service provider }\end{array}$ & 79 & 79 & 80 & 80 & 81 \\
$\begin{array}{l}\text { Passenger satisfaction with the public transport authority } \\
\text { Public transport's market share }\end{array}$ & 63 & 59 & 61 & 61 & 62 \\
\hline
\end{tabular}

might be the fact that the respondents were taking other things than their journey into consideration when assessing the public transport authority, e.g. public transport supply in general. Public transport's market share has increased significantly, from $24 \%$ in 2010 to 27\% in 2014 (Kollektivtrafikbarometern 2015). One interesting aspect is that passenger satisfaction has increased along with increased travel. Historically, in the short term, passenger satisfaction tends to decrease as travel increases, something which can be explained in terms of crowding and delays due to increased numbers of journeys (Kollektivtrafikbarometern 2015) (Table 5).

The data thus indicate that there is a general trend to ward increased travel and increased satisfaction with public transport services. As there are multiple factors of influence, this trend cannot be related to a specific development, e.g. the new Act (Prop. 2009). However, it does indicate that the ongoing changes in Sweden's public transport system are having a positive effect on passenger satisfaction and travel. This assumption is also endorsed by the knowledge that the positive effects of change are often delayed as there can be implementation problems and as it takes time for organizations and employees to understand and adapt to new roles. In assuming that the ongoing changes have influenced the increased level of satisfaction, it is possible that increased collaborative efforts and the service providers' greater influence on market-oriented activities have had a positive effect. 


\section{Conclusions and future research}

The findings clearly indicate that the service providers have increased their involvement in market-oriented activities, while the public authorities' overall involvement in marketoriented activities remains unchanged. Additionally, the service providers have gained a greater level of responsibility, something which is perceived as positive, while the public transport authorities are generally less satisfied with the reallocation of responsibilities. However, both the public transport authorities and the service providers perceive their dyad membership to be contributing both to their knowledge of their passengers' needs and preferences and to their possibilities of effectively responding to customer demands. Also, the dyads are more frequently involved in disseminating activities such as meetings and informal contact. Thus, the findings indicate that the industry as a whole has increased its organizational and dyadic efforts to acquire knowledge of passengers' needs, in addition to efforts to respond to these needs with an increased collaborative focus.

Although there are multiple aspects that can influence the evolution of public transport, the providers' increased market orientation suggests that this evolution has been influenced by the new public transport Act. The reallocation of responsibilities, partly resulting from the legislation, has been aimed at increasing the passenger focus (SOU 2009:39). This indicates the underlying notion that the service providers, with their proximity to the customer, are crucial actors in efforts to increase the market orientation of the industry. However, a highly relevant question here is: What measure of market orientation best depicts the market orientation of the industry? Is it the market orientation of the provider or the public authority that makes the industry market-oriented, or is it a combination and, if so, do they contribute equally? This question relates to the roles of the actors in public transport. As already mentioned, one stated goal of the new Act is to create more clearlydefined roles for the actors (SOU 2009:39). It can be assumed that the need for clearly defined roles also relates to the market orientation of the industry.

Since our findings indicate a lack of clarity concerning responsibilities, further discussions and guidelines might be needed regarding the actors' responsibilities. Researches into which role constellations that foster market-oriented public transport systems would provide some insights; however, it is also reasonable to assume that other influences are important as well. It is therefore reasonable to assume that market orientation can be pursued by using various service delivery models, even within the framework of public procurement. However, a collaborative approach is likely to benefit the industry most since the actors will be able to contribute different perspectives. A shared view of service provision enables successful communication and collaboration, which is likely to contribute to a passenger-centric and market-oriented public transport system.Given the general trend toward adopting public procurement processes and increasingly striving toward market-oriented public transport, the question of responsibility allocation becomes an important issue that should be given further attention by both policymakers and scholars.

Open Access This article is distributed under the terms of the Creative Commons Attribution 4.0 International License (http://creativecommons.org/licenses/by/4.0/), which permits unrestricted use, distribution, and reproduction in any medium, provided you give appropriate credit to the original author(s) and the source, provide a link to the Creative Commons license, and indicate if changes were made. 


\section{References}

Eboli, L., Mazzulla, G.: A stated preference experiment for measuring service quality in public transport. Transp. Plan. Technol. 31(5), 509-523 (2008)

Enquist, B., Johnson, M.: Styrning och navigering i regionala kollektivtrafiknätverk (Steering and Navigation in regional public transport network). Karlstad University Studies 2013:14, Karlstad (2013) [in Swedish]

Fellesson, M., Friman, M.: Perceived satisfaction with public transport services in nine European cities. J. Transp. Res. Forum 47(3), 93-103 (2008)

Helfert, G., Ritter, T., Walter, A.: Redefining market orientation from a relationship perspective: theoretical considerations and empirical results. Eur. J. Market. 36(9/10), 1119-1139 (2002)

Jaworski, B.J., Kohli, A.K.: Market orientation: antecedents and consequences. J. Market. 57(3), 53-70 (1993)

Kohli, A.K., Jaworski, B.J.: Market orientation: the construct, research propositions, and managerial implications. J. Market. 54(2), 1-18 (1990)

Kohli, A.K., Jaworski, B.J., Kumar, A.: MARKOR: a measure of market orientation. J. Market. Res. 30(4), 467-477 (1993)

Kollektivtrafikbarometern.: Svensk Kollektivtrafik. “Årsrapport 2016 KOLLEKTIVTRAFIKBAROMETERN” (Public Transport Barometer Annual Report 2015). http://www.svenskkollektivtrafik.se/ globalassets/svenskkollektivtrafik/dokument/aktuellt/publikationer/kolbararsrapport-2015.pdf (2015) [in Swedish]. Retreived 15 Nov 2016

Maltz, E., Kohli, A.K.: Market intelligence dissemination across functional boundaries. J. Market. Res. 33(1), 47-61 (1996)

Molander, S., Fellesson, M., Friman, M., Skålén, P.: Market orientation in public transport research-a review. Transp. Rev. 32(2), 155-180 (2012)

Pina, V., Torres, L.: Analysis of the efficiency of local government services delivery. An application to urban public transport. Transp. Res. Part A Policy Pract. 35(10), 929-944 (2001)

Prop.: Proposition 2008/2009:93, Mål för framtidens resor och transporter. http://www.regeringen.se/ 49bbc2/contentassets/80dd7d80fc64401ca08b176a475393c5/mal-for-framtidens-resor-ochtransporter-prop.-20080993 (2008) [in Swedish]. Retreived 15 Nov 2016

Prop.: Proposition 2009/2010:200, Ny kollektivtrafiklag. http://www.regeringen.se/49bbc0/contentassets/ b3b5d0bdcf5e47809e9a811bce0b92e7/ny-kollektivtrafiklag-prop.-200910200 (2009) [in Swedish]. Retreived 15 Nov 2016

Redman, L., Friman, M., Gärling, T., Hartig, T.: Quality attributes of public transport that attract car users: a research review. Transp. Policy 25, 119-127 (2013)

Rourke, F.E.: Responsiveness and neutral competence in american bureaucracy. Public Adm. Rev. 52(6), 539-546 (1992)

SFS.: SFS (The Swedish Code of Statutes), 2010. 1065. Lag om kollektivtrafik, Riksdagen, Stockholm. https://www.riksdagen.se/sv/dokument-lagar/dokument/svensk-forfattningssamling/lag-20101065-omkollektivtrafik_sfs-2010-1065 (2010) [in Swedish]. Retreived 15 Nov 2016

SOU.: SOU 2009:39. En ny kollektivtrafiklag. Delbetänkande av utredningen om en ny Kollektivtrafiklag. http://www.regeringen.se/contentassets/32cedfe7172744908879d17353a30e83/en-nykollektivtrafiklag-hela-dokumentet-med-bilaga-1-5-sou-200939 (2009) [in Swedish]. Retreived 15 Nov 2016

Trafa.: Contracts for the procured public transport, Summary Report 2015:13. http://www.trafa.se/ globalassets/rapporter/summary-report/summary-report-2015_13-contracts-for-the-procured-publictransport-2013.pdf (2013) [in Swedish]. Retreived 15 Nov 2016

Trafa.: Improved public transport? An evaluation of two reforms, Summary Report 2014:13. http://www. trafa.se/globalassets/rapporter/summary-report/summary-report-2014_13-improved-public-transportan-evaluation-of-two-reforms.pdf (2014) [in Swedish]. Retreived 15 Nov 2016

van de Velde, D.: A new regulation for the European public transport. Res. Transp. Econ. 22(1), 78-84 (2008)

van de Velde, D.: Market initiative regimes in public transport in europe: recent developments. Res. Transp. Econ. 48, 33-40 (2014)

Vigoda, E.: From responsiveness to collaboration: governance, citizens, and the next generation of public administration. Public Adm. Rev. 62(5), 527-540 (2002)

Walker, R.M., Brewer, G.A., Boyne, G.A., Avellaneda, C.N.: Market orientation and public service performance: new public management gone mad? Public Adm. Rev. 71(5), 707-717 (2011) 
Wejnert, C., Heckathorn, D.: Respondent-driven sampling: Operational procedures, evolution of estimators, and topics for future research. In: Williams, M., Vogt, W.P. (eds.) The SAGE Handbook of Innovation in Social Research Methods, pp. 473-497. SAGE, London (2011)

Sofia Molander is a PhD student in Business Administration at Karlstad University, Sweden. Her research focus is market orientation in public transport. She particularly studies the relationship between public transport actors and its implications for market oriented activities. 